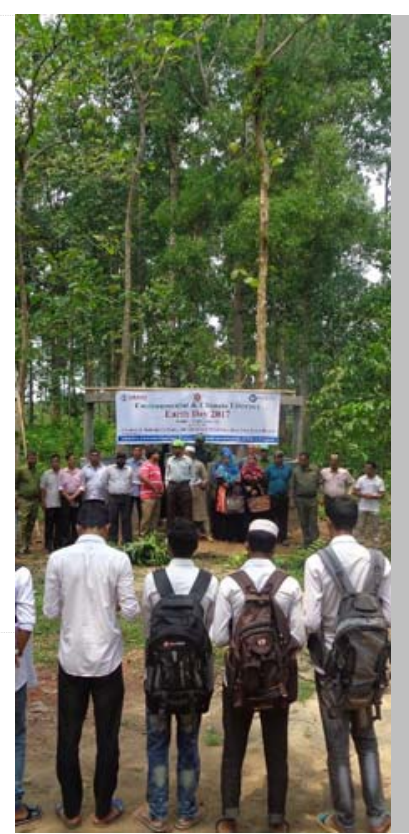

\title{
EVALUATING COLLABORATIVE MANAGEMENT WITHIN THE NATIONAL PARKS AND WILDLIFE SANCTUARIES OF BANGLADESH
}

\author{
Md. Shams Uddin ${ }^{1}$ and John W. K. Parr ${ }^{2 *}$ \\ *Corresponding author: jwkparr103@gmail.com \\ ${ }^{1}$ Manager-Landscape Planning, Ecosystems and Biodiversity, Climate-Resilient Ecosystems \\ and Livelihoods (CREL) Project, Winrock International, Bangladesh \\ ${ }^{2}$ Technical Advisor for Protected Areas Management, Department of Forestry, Ministry of \\ Agriculture and Forestry, Vientiane, Lao P.D.R
}

\section{ABSTRACT}

The protected area system of Bangladesh in March 2017 comprised 17 national parks covering 45,740 hectares and 21 wildlife sanctuaries covering 394,053 hectares. The Government of Bangladesh introduced collaborative management in these reserves in three successive, expanding phases undertaken between 2003 up until the present time. During this period, the successive programmes introduced an elaborate collaborative management system. This paper evaluates this collaborative management system as well as the protected area management arrangements being promoted, comprising: (i) the Co-management Council, (ii) the Co-management Committee, (iii) the People's Forum, and (iv) sub-village institutional bodies including the Community Patrol Groups and the Forest User Groups (or the Village Conservation Forums). It assesses the management interventions and the effectiveness of the collaborative management system to implement an effective protected area programme. The review indicates that the current organisation and mandate of the protected area authorities precludes them from being effective partners in collaborative management, lacking dedicated staff in both the outreach and livelihood agendas, which severely undermines their participation in collaborative management. This paper recommends that the protected area authority needs to be strengthened and reorganised, in order to play a leading role in village engagement - and a key leading agency in the higher level collaborative management bodies.

Key words: Bangladesh, co-management, collaborative management, national park, protected area, wildlife sanctuary

\section{INTRODUCTION}

Various management terms - including joint management, shared governance and co-management have been proposed as approaches for management of protected areas worldwide (Carlsson \& Berkes, 2005; Rashid et al., 2013, 2015). Co-management has also been proposed to provide opportunities to share responsibilities, rights and duties between the government and local resource users (Berkes et al., 1991; World Bank, 1999; Carlsson \& Berkes, 2005; Parr et al., 2013). However, in Asia, government conservation agencies across the region have often been awarded management responsibility over the past 3050 years for the biologically rich tracts of natural habitats within their respective countries. With very few exceptions (e.g. Lao PDR and the Philippines), these conservation agencies have managed these sites for varying numbers of decades, without meaningful engagement of the local communities (De Koning et al., 2016). The transition from fortress-type management approaches to collaborative management approaches involves not only a policy change, but institutional organisational changes within the protected area bodies themselves managing the protected areas (Chowdhury et al., 2009). Collaborative management - and the gradual shift towards co-management - requires the training of field staff, from managers downwards, so that they actually have the necessary skill sets to engage in collaborative management with the district partner agencies and the villagers themselves; becoming comanagement partners takes decades. Hence, we adopt the term "collaborative management" which takes account of the anticipated 20-30 year period for government conservation partners to engage, understand and accept villagers as (co-)management partners. 


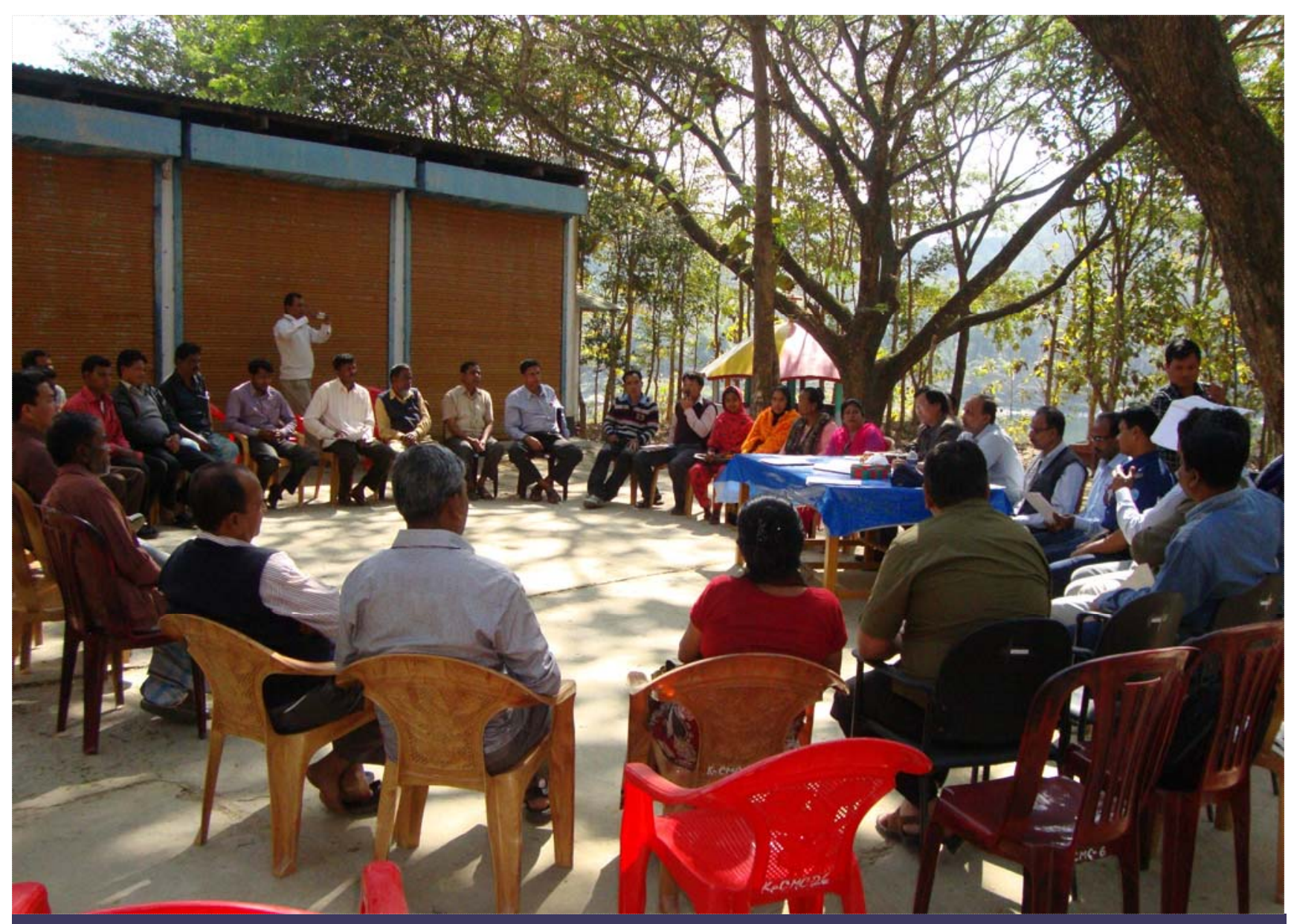

Monthly Co-Management Committee (CMC) meeting including Forest Department staff, community representatives, civil society and law enforcing agency staff (๑) Md. Shama Uddin

The principles of collaborative management, like comanagement, include the use of local people's knowledge in resources conservation. It incorporates traditional and scientific knowledge into protected area management, and integrates a variety of actors in a variety of roles in natural resource management. It promotes continuous consultation through a learningby-doing approach, encouraging decentralisation of management power, biodiversity conservation and planning at the local level and participatory learning, (Berkes et al., 1991; Borrini-Feyerabend et al., 2004; Carlsson \& Berkes, 2005; Arnold \& Gimenez, 2007), which are the basis for the acceptance of collaborative management by protected area managers.

The establishment of the protected area system in Bangladesh was launched in the 1960s through the declaration of national parks and wildlife sanctuaries under the Forest Act (1927) and the Wildlife Preservation Act (1974) (Huda, 2006; Sharma et al., 2008; Chowdhury \& Koike, 2010). As of 31 March 2017,
Bangladesh had 38 protected areas comprising 17 national parks covering 45,740 hectares and 21 wildlife sanctuaries covering 394,053 hectares. These protected areas are valued for supporting the livelihoods of the dependent communities (Mukul et al., 2010) and indigenous communities (Mian et al., 2013). Bangladesh is a country facing high population density, resource scarcity and extreme pressures on its forests (Mukul et al., 2010; Sohel et al., 2014). Collectively, these factors result in high threat levels within the protected area system from local villagers, including cutting saplings for firewood, uncontrolled grazing, forest fire outbreaks, illegal selective logging, as well as conversion of lands into agriculture and housing (Rashid et al., 2013; Chowdhury et al., 2014; Palomo et al., 2014; Rahman \& Vacik, 2015). Furthermore, due to changes in temperature and rainfall patterns, the overall health and condition of the protected areas are degrading (Pender, 2008).

In response to the prevailing situation, the Government of Bangladesh introduced collaborative management 
into five protected areas through the Nishorgo Support Project (NSP) undertaken between 2003 and 2008 in order to develop a model which could be gradually replicated to other protected areas of the country (Quazi et al., 2008). This pilot initiative involved the sharing of management responsibilities with other stakeholders, including local villagers (Fox et al., 2007; Ferdous, 2015). In 2006, eight Co-management Committees were formed within the five sites, based upon the number of ranges found in the respective sites. The Forest Department developed the Nishorgo Vision 2010 to implement collaborative management. Subsequently, the Forest Department increased the collaborative management programme to a further 13 protected areas (as an overall total of 18 protected areas) involving a further 15 Co-management Committees through the Integrated Protected Area Co-management (IPAC) Project undertaken between 2008 and 2013, covering 185,088 hectares. Significantly, co-management was incorporated into the Wildlife Conservation and Security Act (Amendment, 2012). In 2013, the Forest Department expanded and strengthened the collaborative management programme, targeting a total of 22 protected areas and involving 27 Co-management Committees through the ongoing USAID-funded, Climate-Resilient Ecosystems and Livelihoods (CREL) Project.

During the 13 years of implementing collaborative management in Bangladesh, various challenges were recognised including the failure to establish the Forest Department as a leading partner with the local villagers within the key institutional bodies under the collaborative management system, the complexity of the institutional structures, the influence from local political parties, as well as project dependency and finances (Baldus, 2008; Cardinale et al., 2012; Rashid et al., 2013; Chowdhury et al., 2014). Despite these challenges, community participation in local forest management brought substantial positive impacts and collaborative management has gained popularity among people involved in the conservation and protection of biodiversity and ecosystem services of protected areas (Rashid et al., 2013; Mukul et al., 2015).

This paper investigates the challenges regarding the effectiveness of collaborative management within the protected areas of Bangladesh with the aim of generating alternative solutions, through:

1. A detailed analysis of the institutional arrangements of; (a) the protected area authorities, and (b) the governance mechanisms for their interactions with local stakeholders; and

2. Inferences from the institutional mapping analysis on the collaborative management issues and the current management responses.

\section{METHODOLOGY}

A systematic analysis of the collaborative management system was undertaken, involving the following steps:

1. The development of the collaborative management engagement of the protected area authorities with the local communities was assessed in the relevant legislation, including the prescribing of the institutional bodies involved in the collaborative management system.

2. The organisational arrangements of the protected area authorities of the national parks and wildlife sanctuaries were reviewed, to see how they are structured with regards to implementing collaborative management in the various technical fields of protected area management found in Asia.

3. The institutional bodies prescribed for implementing collaborative management were analysed to understand what their memberships, their functions and responsibilities were, the frequency of meetings and how they interacted within the multi-tiered collaborative management system; and

4. The field activities undertaken during the three successive phases of the collaborative management programme, namely the Nishorgo Support Project (NSP) (2003-2008), the Integrated Protected Area Co-management (IPAC) Project (2008-2013) and the ClimateResilient Ecosystems and Livelihoods (CREL) Project (2013- 2017), were reviewed.

\section{RESULTS}

\section{Protected area management arrangements}

The management authorities of the national parks and wildlife sanctuaries should be a core institutional body at the centre of the collaborative management system, and should be a primary partner in implementing collaborative management in and around the protected areas. The authors evaluated the management system and staffing levels for a typical national park and a typical wildlife sanctuary, which were deemed representative of the collaborative management system 
and issues found more broadly within the protected area system of Bangladesh. In Himchari National Park, these staffing levels were approximately half the required staffing levels as prescribed in the Himchari National Park Management Plan (2016- 2025). In Rema -Kalenga Wildlife Sanctuary, comprising 1,795 ha, staffing levels were also lower than the levels prescribed in the Rema-Kalenga Wildlife Sanctuary Management Plan (2016-2025).

In both reserves, the overwhelming number of staff are dedicated to law enforcement and forest protection (Table 1). Current staffing levels on enforcement were deemed inadequate in both reserves, so additional enforcement staff are proposed within both respective management plans. In sharp contrast, both reserves lack dedicated outreach and conservation awareness staff which are prerequisite to facilitating engagement with the villagers. Collaboration with the buffer zone communities was confined to promoting plantations, with extremely limited opportunities for meaningful engagement with individual villagers. These institutional staffing weaknesses found within these two randomly selected reserves are indicative of the fieldlevel management arrangements found throughout the protected area system of Bangladesh. The low staffing levels contribute to the lack of staffing specialisation required for collaborative management.

\section{Collaborative management institutional bodies at different levels}

The collaborative management system in Bangladesh has four different levels. The two upper level institutional bodies are multi-stakeholder collaborative management bodies, while the lower two levels comprise institutional bodies comprising village representatives at the village level and sub-village level. These four tiers of the collaborative management system comprise (Figure 1):
1. the Co-management Council;
2. the Co-management Committee;
3. the People's Forum; and
4. sub-village bodies including the Community Patrol Groups and the Forest User Groups (or Village Conservation Forums).

\section{The Co-management Council}

Every forest protected area has one or more Comanagement Councils, promoting effective participation of the local stakeholders living around the protected area. The Co-management Council is a general body for policy development, with a membership of 65 stakeholders. Members of the Co-management Council are appointed for four years. The Co-management Council meets at least two times a year.

\section{The Co-management Committee}

The Co-management Committee constitutes the key collaborative management body in Bangladesh. The Committee is elected for two years; any elected member shall not be a member more than two times consecutively. The Co-management Committee meets at least once a month.

\section{The People's Forum}

The General Committee of the People's Forums was constituted with elected representatives from the Village Conservation Forums in villages adjacent to the forest protected areas, consisting of 11 village members.

Table 1. Staffing levels in a typical national park and a typical wildlife sanctuary in 2015

\begin{tabular}{|c|c|c|c|c|c|c|}
\hline Protected area & $\begin{array}{l}\text { Area } \\
\text { (hectares) }\end{array}$ & $\begin{array}{l}\text { No. of } \\
\text { Ranges }^{\mathrm{a}}\end{array}$ & $\begin{array}{l}\text { No. of } \\
\text { Beats }^{b}\end{array}$ & $\begin{array}{l}\text { Enforcement } \\
\text { staff }\end{array}$ & $\begin{array}{l}\text { Outreach } \\
\text { staff }\end{array}$ & $\begin{array}{l}\text { Livelihoods } \\
\text { staff }\end{array}$ \\
\hline Himchari National Park & 1,727 & 1 & 5 & 21 & None & None \\
\hline Additional staff required & & & & 22 & & \\
\hline Rema-Kalenga Wildlife & 1,795 & 1 & 3 & 29 & None & None \\
\hline Additional staff required & & & & 15 & & \\
\hline
\end{tabular}

a A Range Office, composed of 3- 5 beats depending on the area of the Range, is managed by a Range Officer. A Comanagement Committee is usually based on the range jurisdiction with the Range Officer designated as the member secretary of the Co-management Committee.

b A Beat is the lowest administrative unit of the Forest Department. A Beat Officer is in charge of a Beat. 


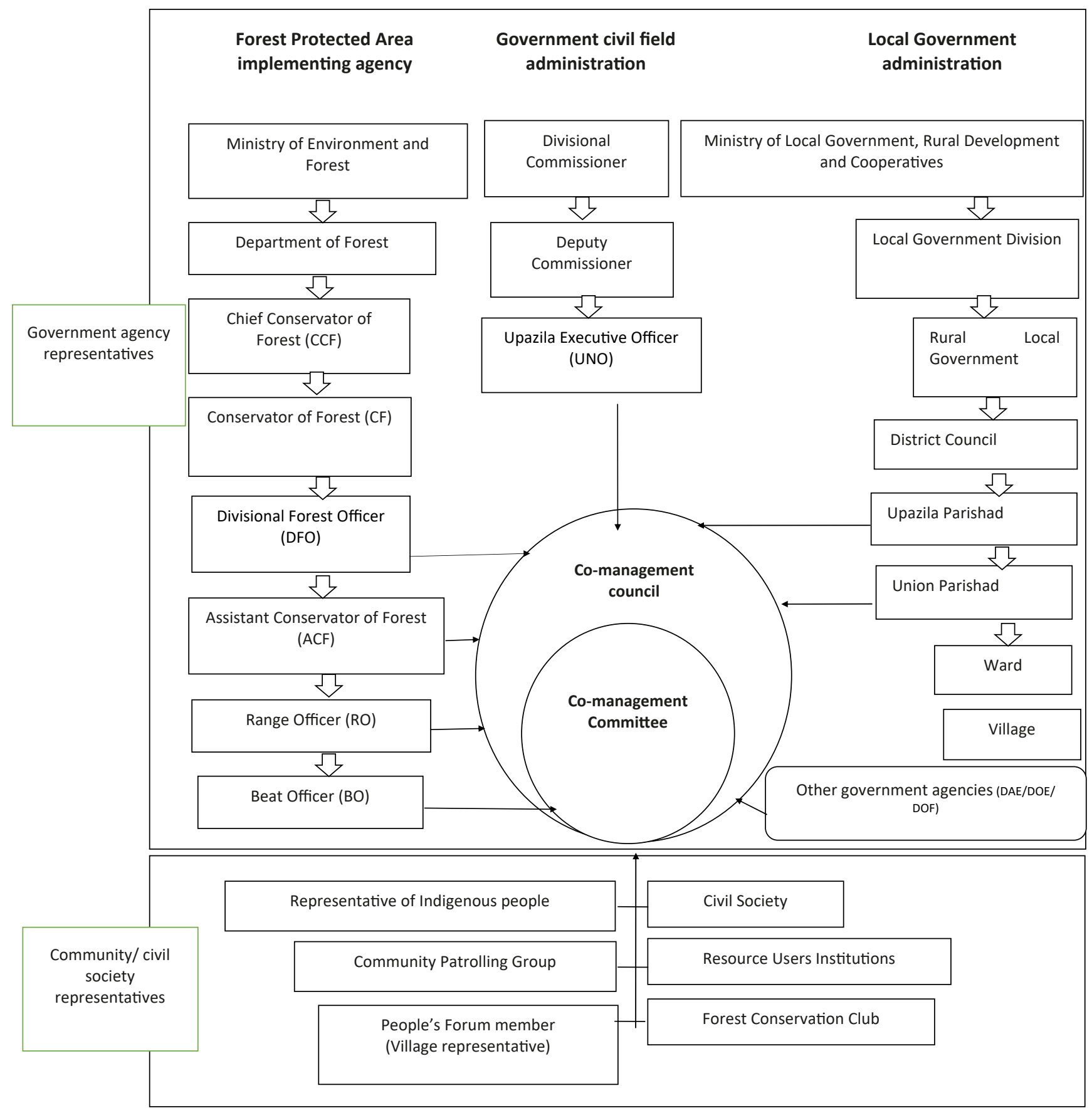

Figure 1. Two main co-management bodies - the Co-management Council and the Co-management Committee in relation to (i) the Forest Protected Area agency, (ii) the Government civil administration and (iii) the Local Government Administration. 


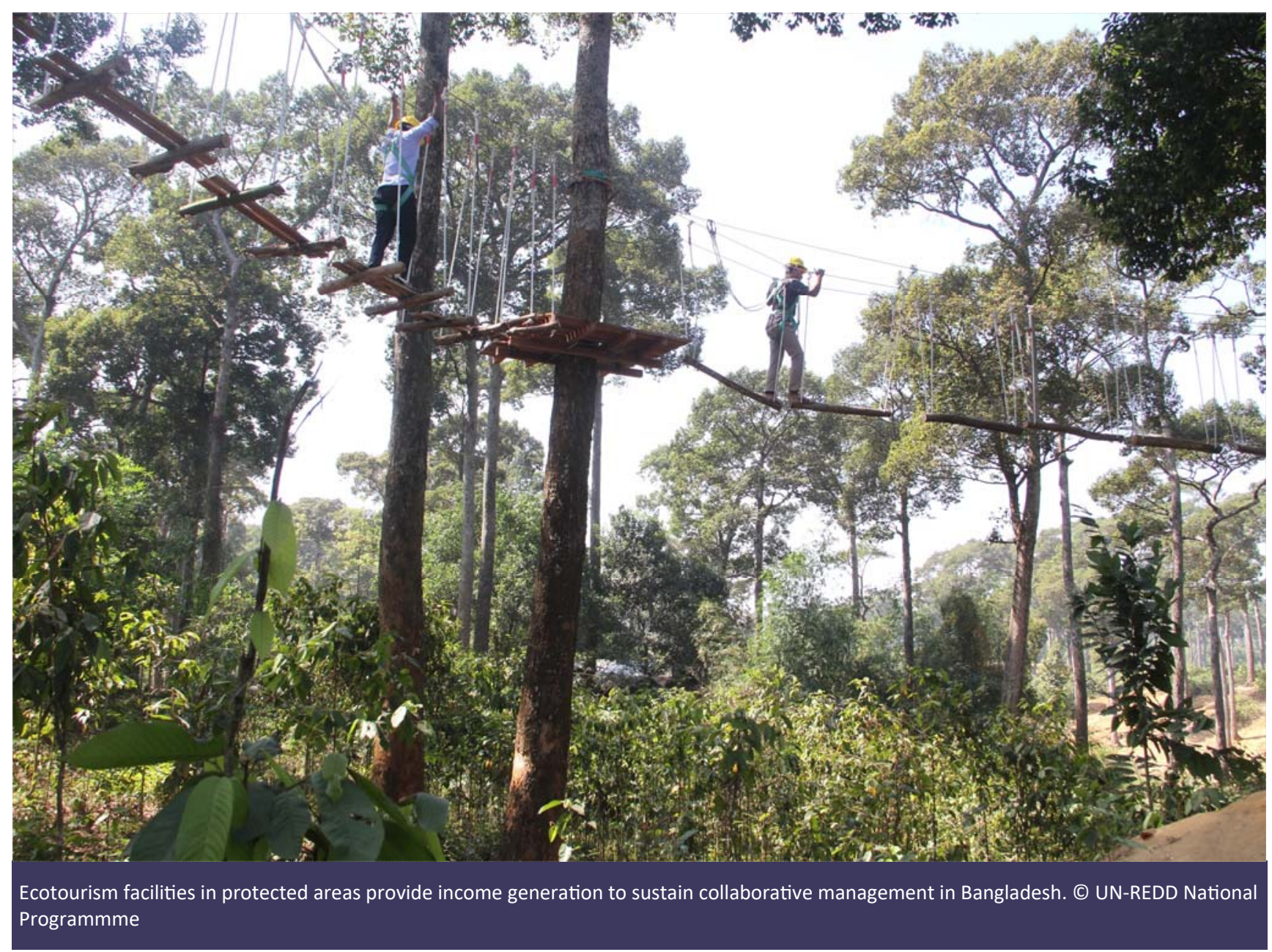

Sub-village institutional bodies

(a) Community Patrol Groups

A total of 75 Community Patrol Groups protect 43,974 hectares of protected areas in Bangladesh. Each month group members meet together to discuss threats, protection and the next course of action. Community patrolling work is mostly voluntary. They patrol for 6- 8 days a month. Training has been provided on conservation, protection and the responsibilities of patrol group members. Of note, the patrol members have no land tenure relationship to the natural resources which they are protecting. Since the patrol groups began patrolling in 2006, three patrol members have been killed and a further 68 severely injured while on patrol.

(b) Forest User Groups

Forest user groups comprised those members of the local communities who were heavily dependent upon the natural resources from the protected areas. The members were selected by the village committee themselves. These Forest User Group members were given development assistance priority because of their heavy dependence on the natural resources. These Forest User Groups were replaced in 2006 by the Village Conservation Forums.

(c) Village Conservation Forums

The Village Conservation Forums were formed during the IPAC to promote conservation and sustainable development in each village around the protected areas. They comprise individual villagers who are interested in the conservation of the forest resources.

\section{Initiatives promoting collaborative management}

The Forest Department implemented three projects with financial assistance from USAID to introduce collaborative management in protected areas in Bangladesh since 2003. Additional details of projects are provided in Supplementary Online Material.

The Nishorgo Support Project (NSP) from 2003- 2008 This project piloted collaborative management in five protected areas comprising Lawachara National Park, Sathchari National Park, Rema-Kalenga Wildlife 
Sanctuary, Chunati Wildlife Sanctuary and Teknaf Wildlife Sanctuary. The project established eight Comanagement Committees, as well as People's Forums, and Forest User Groups.

Integrated Protected Area Co-management (IPAC) Project from 2008- 2013

The project expanded the collaborative management system into a further 13 protected areas (targeting an overall of 18 protected areas) involving the mobilisation and technical support to total of 23 Co-management Committees.

Climate Resilient Ecosystems and Livelihood (CREL) Project, from 2013- 2017

Under this project the Forest Department expanded collaborative management in 22 protected areas with 27 Co-management Committees. The initiative facilitated the development of 14 protected area management plans and 27 long-term (10-year duration) comanagement plans.

\section{DISCUSSION \\ Rapid legal changes promoting collaborative management of protected areas}

The mainstream forestry legislation (Forestry Act, 1927) in Bangladesh precluded access to local people, for almost 80 years; a period of sufficient duration to facilitate a strongly ingrained attitude among forestry officials regarding community participation in protected area management. After the Liberation War in 1971, the Government of Bangladesh included a section (18A) in the Constitution which states that the "State will conserve and develop the environment for people and will ensure conservation and security of forests, wildlife, wetlands, biodiversity and natural resources". Consequently, the Bangladesh Government enacted a number of new policies and instruments relating to promoting collaborative management in protected areas. The government notified a gazette on comanagement in 2006 (amended in 2009) to introduce collaborative management within the five pilot comanaged protected areas. Collaborative management was also recognised by the Wildlife Preservation Act (Amendment, 2012), which stated that: "the government may introduce co-management system for proper utilization, conservation and management of natural resources of the sanctuary involving the Forest Department, minor ethnic-communities living in the forests or local communities on participatory basis to ensure active participation of all the parties therein".

\section{General observations on the collaborative management system}

The majority of the protected areas established before the 1980s followed exclusionary state-run approaches, restricting the customary user rights of the local communities (Mehta \& Heinen, 2001). The challenge for the development of collaborative management has been to overcome the colonial legacy characterised by bureaucratic and revenue-oriented management, and widespread isolation of communities by ignoring their traditional rights, indigenous knowledge and resource use practices (Rashid et al., 2017). In this context, the collaborative management system in Bangladesh developed extremely rapidly. It was therefore somewhat optimistic to consolidate the identification of the two key institutional bodies for collaborative management the Co-management Council and the Co-management Committee - based entirely upon the outcomes and recommendations of a single project initiative, the NSP (2003-2008), without trialling a range of collaborative management models, and evaluating their internal institutional and governance mechanics.

The system proposed and adopted comprises a multitiered governance system in which the two highest level multi-stakeholder institutional bodies discuss the full range of protected area issues. These two higher institutional bodies immediately link into the grassroots village forums, namely the People's Forums and the Forest User Groups (or Village Conservation Forums). The Bangladesh collaborative system contrasts strongly with the collaborative management arrangements found within other protected areas in Asia, which have committees dedicated to different technical areas of management, which have evolved over longer time frames. Mount Kitanglad Range Natural Park, mooted as one of the best protected area collaborative management systems in the Philippines, has no less than 13 committees operating under the Protected Area Management Board and Executive Protected Area Management Board, with each committee dedicated to focus on a particular protected area issue (Parr, 2017). Periyar Tiger Reserve also has a wide range of institutional bodies tackling various issues found in landscape protected area management (Parr, 2015).

This 'vertical' collaborative management phenomenon in protected area management in Bangladesh may have been induced by the lack of diversity of job roles and responsibilities awarded to the forestry staff, or by individuals who think that stakeholder dialogue forums alone promote effective co-management; without 
training of the collaborative management partners, they almost certainly do not. It is unclear what role was envisaged for the Forest Department in the three successive collaborative management projects, and what training or technical expertise was added to its mandate. However, this may well account for the degree of ambiguity between the role and responsibilities of the Forest Department and the collaborative management bodies in field operations, as reported by Rashid et al. (2015). The lack of focus on discussing technical agendas, also leads to the predominance of elite groups in the collaborative management bodies. Quite simply, too few members have been appointed with technical knowledge, whilst too many members have been elected with their own agendas. Chowdhury et al. (2014) reported a lack of policy level integration in all 34 protected areas, and cited this as the biggest threat to biodiversity conservation in protected areas.

According to Haider and Kabir (2014), a number of stakeholders complained that the working body of the Co-management Committee was not always effective in engaging local people in decision-making. The stakeholders claimed that there is a communication gap between the Co-management Committee, the Village Conservation Forums and local villagers, which is sometimes responsible for the unsuccessful conservation approaches. Rashid et al. (2017) also recommend devising an appropriate governance mechanism recognising and supporting local rights, access and participation in protected area management. The Forest User Groups, which constitute a valuable institutional body for sustainable management of the protected areas, have had their mandates broadened into the Village Conservation Forums. It may be worth reconstituting the Forest User Groups, which could be targeted for development assistance, to mitigate threats to the protected areas. These groups should be linked into the government administrative system, through the Union Parishad and Wards.

Local political people are important stakeholders in collaborative management. However, sometimes politically influential individuals misuse their power by overshadowing the voices and interests of people at the grassroots (Jashimuddin \& Inoue, 2012), and are themselves involved in illegal poaching and resource collection from the forest (Fox et al., 2007; Uddin \& Foisal, 2007; Uddin \& Mukul, 2007; Muhammed et al., 2008). On many occasions illegal logging and encroachment inside the protected areas benefitted and were supported by political leaders (Rashid et al., 2013; Ferdous, 2015).
Weak organisational arrangements of the protected area management authorities for village engagement The organisational arrangements of Himchari National Park and Rema-Kalenga Wildlife Sanctuary, including the proposed staffing levels stated in their respective management plans, suggest that the Forest Department has been unable to restructure its management authorities to the extent required to effectively engage in collaborative management. In both reserves, the overwhelming number of staff are dedicated to forest protection, and there is an extremely limited mandate, and perhaps capacities, at the lowest management levels to collaborate with the buffer zone communities. Forestry staff were only appointed to promote plantations. There were no dedicated protected area staff in either reserve to promote outreach and conservation awareness - to change village attitudes and behaviour - and there are no dedicated staff to facilitate livelihood interventions, and ensure that they link to threat mitigation. According to Kolahi et al. (2013), failing to build connections with the local people is the main cause of the unsuccessful management approaches in the protected areas. This lack of connectivity might be a result of no Forest Department staff having been trained in (i) outreach and conservation awareness and (ii) facilitating livelihood development for conservation; two core requirements for meaningful engagement with local communities.

Such collaborative management arrangements were alluded to indirectly by Kopylova \& Danilina (2011), proposed by Appleton et al. (2003), and elaborated by Parr et al. (2013). A good multi-level collaborative management system has been developed in Periyar Tiger Reserve in Southern India (Parr, 2015). In this regard, the piloting of village engagement crucially involves outreach and livelihoods agendas - and thence bringing about attitudinal changes among the Forest Department officials towards the shifting paradigm in protected area management.

Absence of coherent outreach programmes to villagers All three collaborative management initiatives overlooked the need to establish dedicated outreach and conservation awareness staff in the targeted protected areas over the 14-year agenda of promoting collaborative management within the protected area system of Bangladesh. Under the NSP (2003-2008), the outreach and school programmes for conservation were implemented by the project staff. Key outreach activities under the IPAC Project (2008- 2013) involved arranging a co-management congress, promoting responsible tourism campaigns, youth engagement in conservation, radio programmes, journalists' visits, cross-site visits, art competitions and local theatres, and participation in 
different national and international events. In 2009, the sharing of entrance fees in protected areas with local communities was initiated in five protected areas through the Co-management Committees. More diverse outreach activities were undertaken under the CREL Project (2013-present), including youth engagement, cross-site visits, national and international day observance, signage, jungle walks, newsletters, leaflet flyers, journalists' visits to protected areas, community radio programmes, tourism promotion activities, and various capacity-building courses at home and abroad aimed at co-management and Forest Department staff.

Management of outreach is diffused across comanagement bodies. Co-management Committees are mandated to arrange various meetings, training, workshops and public awareness programmes to increase the awareness of villagers on biodiversity conservation, with no lead agency specified. Both the People's Forums and the Village Conservation Forums are also mandated to promote outreach and conservation awareness among their village communities. However, no government capacities "on (i) raising awareness regarding the conservation of natural resources and wildlife, (ii) raising awareness about sustainable livelihoods, including sustainable utilisation of non-timber forest products, (iii) raising awareness among villagers regarding climate change and (iv) encouraging villagers to abide by the existing forestry conservation legislation", were envisaged in successive project designs.

To contest these mandates, Ferdous (2015) stated that most of the poor villagers have little or no idea about biodiversity conservation. He recommended that steps should be taken by the protected area agency itself to make villagers aware of species conservation as well as the links to deforestation, global warming, climate change and their consequences. Open dialogue and community engagement will foster stronger ties, and assist in alleviating various illegal practices including poaching and resources extraction (Abbasi \& Khan, 2009; Steinmetz et al., 2014; Dhakal \& Thapa, 2015). A number of authors also point to the importance of understanding local peoples' perceptions of protected areas (Lynam et al., 2007; Allendorf et al., 2012), which can guide management decisions (Parry \& Campbell, 1992; Weladji et al., 2003). Parr et al. (2013) recommend that a defined community outreach section within the protected area management authority is required.

Sustainable utilisation of natural resources in protected areas

Traditional utilisation of non-timber forest products from the forest protected area system of Bangladesh

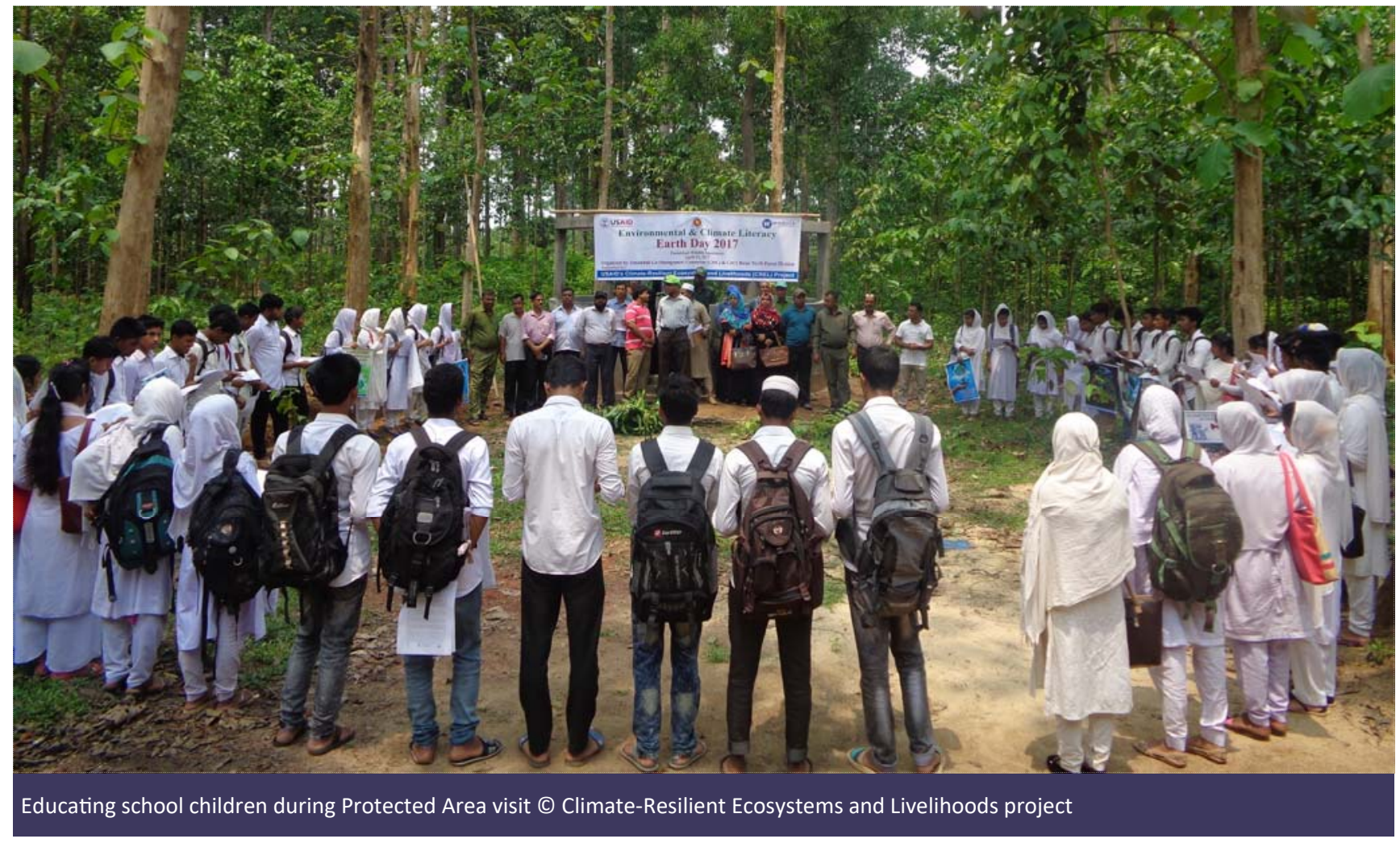


appears widespread, and represents a significant proportion of livelihood income. It also represents a particularly vital source of income to landless villagers. In Satchari National Park, Mukul et al. (2012) discovered that local communities gather a substantial amount of non-timber forest products despite official restrictions. They found that 27 per cent of households living in close proximity to the protected area received at least some cash benefit from the collection, processing and selling of non-timber forest products, and non-timber forest products contribute to households' primary, supplementary and emergency sources of income. They also reported that non-timber forest products also constituted an estimated 19 per cent of households' net annual income, and were the primary occupation for about 18 per cent of the households. The forests provide food, fodder, fuel, medicines and building materials. To avoid conflict and promote the traditional livelihoods of the communities, there is a need to allow local people to harvest certain amounts of forest products to ensure ecological sustainability (Mukul et al., 2010, 2012).

There is a strong link between poverty and dependence upon the forest. In Kaptai National Park, Mian (2011) found that approximately 36 per cent of households in Bangchari and 57 per cent of households in Kamillachari have no agricultural land. The landless in both villages collect and sell fuel-wood and other nontimber forest products from neighbouring forests. In Madhupur National Park, 82 per cent of households in the village of Pirgacha engage in forestry activities inside the national park. Fuel-wood is collected from the park's forests by 75 per cent of households for daily consumption and also for sale (Mian, 2011). He found that 20 per cent of households collect wood and that 18 per cent collect fruits and leaves from forests. Approximately 36 per cent of households own land. In Telki Village, all the households collect fuel-wood from the national park both for household consumption and for sale (Mian, 2011). In addition, 84 per cent collect wood and 12 per cent collect fruit and leaves from the forest. In Telki, 32 per cent of respondents own land.

Given these realities, the three co-management initiatives overlooked an opportunity to conduct participatory research involving protected area staff and the villagers to enable the Forest Department staff to understand the social dynamics of natural resource utilisation. This in turn could have led to the piloting of village land use planning, and the subsequent zoning of the protected areas to facilitate sustainable natural resource extraction, linked to village rules. Instead, alternative livelihoods were promoted.
Livelihood development interventions linked to threat mitigation

The three successive programmes delivered a wide range of livelihood interventions, some directly linked to threat mitigation and some indirectly linked to threat mitigation. However, the protected area staff were not given a facilitator role in the delivery of these interventions, and hence again missed an opportunity to make the protected area staff a core co-management partner. Under the NSP (2003-2008), livelihood interventions activities were introduced by the Comanagement Committees with support from the project staff; the protected area staff were not trained and designated as the collaborative management partners for implementing these activities, plantations aside. A total of 102 Forest Users Groups were established comprising 1,750 of the most forest dependent households, to reduce their forest dependence. Interventions included homestead tree plantations, bamboo management and improved cooking stoves, as well as linkages to micro finance institutions, handicrafts, tourist stalls and eco-cottages. The project provided households with training in cow fattening, nursery establishment, fish cultivation, fishing, pig rearing, poultry rearing, small trading, rickshaw-van pulling, manufacturing of improved cooking stoves, and eco tour guiding. Under the project, the Co-management Committees received development funding amounting to BDT 8,989,303 (US\$ 113,788) to implement livelihoods and ecosystems improvement activities.

Through the IPAC Project: 2008-2013, the collaborative management systems received a further BDT 4,565,442 (US\$ 57,790) to manage the forest ecosystems and promote livelihoods interventions. Important livelihoods activities comprised nursery establishment, bamboo handicrafts and weaving, homestead vegetable gardening, mushroom cultivation, poultry rearing, eco tour guiding, tailoring, and leveraging funds from other projects. All these livelihood interventions were facilitated by the project staff; the protected area staff were not trained and designated as the collaborative management partners for these activities. In stark contrast, in Periyar Tiger Reserve, the protected area authorities recruit a livelihoods development facilitator who leads on the delivery of the livelihood interventions, and promotes sustainable buffer zone livelihoods (Parr, 2015).

The CREL Project: 2013- 2017 also developed 400 local service providers, 2,760 agriculture demonstration plots and engaged 3,900 women in export-oriented toy making. The project identified market-based livelihoods by providing market-based training, and linkage with 
buyers and market actors, creating local service providers. The project also strengthened nonagricultural employment for natural resource users including the landless through private sector engagement. New economic opportunities through food processing and ecotourism for resource dependent people were created by the project. The project also introduced non-agriculture based livelihood activities included vocational training on souvenir making, jute/ paper bag making, crop seed production, handicrafts production and crab fattening. Further, the project included 350 Financial Literacy and Entrepreneurship Development Centres targeting 6,200 beneficiaries, mostly women, who each received seven months of training.

\section{Successful joint patrolling with villagers}

All three development initiatives promoted the recruitment and employment of local villagers as community patrol staff, who have provided much needed additional human resources to implement the law enforcement activities within the protected areas. Under the NSP Project (2003-2008), community patrol teams, comprising 927 local villagers, undertook joint patrolling with local forest officials. They were provided minimum honoraria. The IPAC also supported this law enforcement approach, facilitating the establishment of community patrol groups comprising 643 village members. The CREL (2008-present)
Project helped the Forest Department to recruit 185 community patrol members in the Sundarbans reserve forests. However, it remains unclear whether the strong law enforcement programmes endeared the protected area staff to their villagers who are their collaborative management partners.

Financial sustainability of collaborative management All the protected areas in Bangladesh are facing an acute funding shortage, hampering the sustainability of forest protection and biodiversity conservation (Chowdhury et al., 2014). Bangladesh has extreme resource constraints, and its government cannot allocate sufficient funds from the public budget to the forestry sector owing to other priorities (Mulongoy et al., 2008). The long-term sustainability of the entire Co-management Committee system remains an issue. One observation is that all the institutional bodies prescribed in the current comanagement system are project-derived institutional bodies, operating outside the existing administrative system of Bangladesh. Rashid et al. (2017) recommend that these issues need consideration in designing future protected area regimes, in the perceived absence of external aid support.

Ecotourism represents one of the most viable options for delivering benefits to the local communities in protected areas (Nagothu, 2001; Fox et al., 2007; Haider \& Kabir, 2014). Revenue sharing from ecotourism will assist in

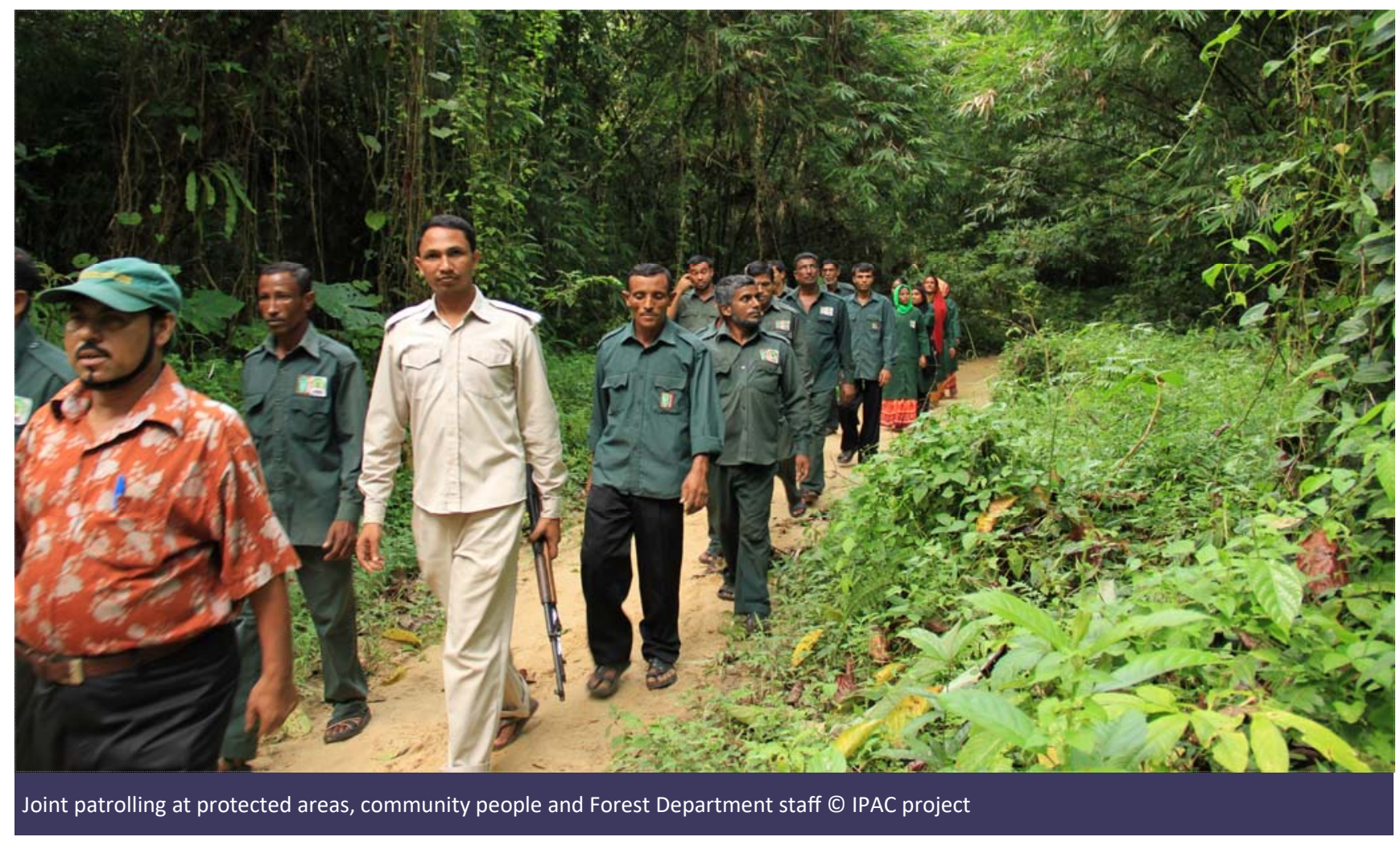


maintaining the financial sustainability of the collaborative management programme. However, the Forest Department collects entry fees from Himchari National Park and Bhawal National Park through open bidding, without sharing these benefits with the respective Co-management Committee. Increasing ecotourism facilities will increase opportunities for comanagement financial sustainability. Khadimnagar National Park, Kaptai National Park, DudpukuriaDhopachari Wildlife Sanctuary, Hazarikhil Wildlife Sanctuary, Fasiakhaki Wildlife Sanctuary, Medhakacchapia National Park, Nijumdwip National Park and Inani Reserved Forest (proposed protected area) all show potential for developing ecotourism. Finally, co-management has the potential to collect revenue from non-timber forest products, further revenue from entry fees to protected areas, the introduction of payment for ecosystem services, REDD+, public private partnerships, access to donor funding and the Climate Trust and Resilience Fund of the Bangladesh Government.

\section{CONCLUSIONS}

Collaborative management has become an acceptable management strategy for the forested protected areas in Bangladesh, and appears to be strongly supported at policy level, with donor support. However, the potential benefits of collaborative management are yet to be seen in Bangladesh because of some extremely fundamental flaws in the institutional collaborative management arrangements. Most significantly, the protected area staff have not been organised, trained and mandated to be effective collaborative management partners with the villagers and district partners. No outreach and conservation awareness units or livelihood development for conservation units have been established, rendering the officials of the national parks and wildlife sanctuaries poor collaborative management partners.

As a direct consequence of the limited participation of the protected area authorities, the Co-management Committees, and to a lesser extent, the Co-management Councils, have become project forums to deliver project activities, with technical stop-gapping by the project staff substituting themselves and other district partners to guide the outreach and livelihood programmes. These institutional arrangements are highly unsustainable. Some very simple structural changes are required to bring in the Forest Department as the lead collaborative management partner, and as a leading partner in outreach and livelihood development linked to threat mitigation. An important natural resource issue is villager access to non-timber forest products. This activity still needs some evaluation through piloting in a couple of protected areas, involving international experts in forest and land use planning, and village forest management. Livelihood interventions need clear links to participatory threat mitigation.

The institutional arrangements for collaborative management need to bridge the technical programmes of the protected area authorities with the administrative agendas of government. These modifications should ensure the long-term sustainability and better forest governance of the protected areas in Bangladesh.

\section{Recommendations}

The entire collaborative management system revolves around stakeholder meetings being convened at the different levels. The membership and agendas of the Comanagement Councils and Co-management Committees should be reviewed given the proposed role of protected area staff to lead outreach and conservation awareness programmes as well as livelihood development for conservation programmes within the neighbouring villages.

To assist the restructuring process of both the Comanagement Councils and the Co-management Committees, research should be conducted to assess the effectiveness of both these institutions in supporting effective collaborative management interventions.

One or more selected protected areas, should pilot test a possible restructuring of the Co-management Committee into three specialised committees, focussed on (i) law enforcement; (ii) promoting sustainable livelihoods and capacity development, (iii) outreach. Efforts should be made to align these specialised Comanagement committees with existing government administrative structures including the sub-districts (Upazilas/Thana), union councils (Union Parishads) and villages (Wards) to increase sustainability.

The Forest Department, assisted by donor support, should pilot the recruitment of rural development/ livelihood experts within the management structure of national parks or wildlife sanctuaries to facilitate sustainable livelihood and threat mitigation interventions in the buffer zone.

The Forest Department, assisted by donor support, should train selected forestry staff to facilitate outreach and conservation awareness programmes within buffer zones.

Piloting of law enforcement strategies, involving selected community patrol groups, protected area law enforcement staff and perhaps district police should be 
promoted to provide a mobile higher level of enforcement inside the protected areas.

The Forest Department should promote a national level collaborative management working group, bringing together expertise from government agencies, academia, recognised experts and NGOs to supervise the development of collaborative management in protected areas in Bangladesh. Expertise should be sought to cover the full spectrum of protected area issues.

The Forest Department, in collaboration with the national level collaborative management working group, should investigate use of site level protected area trust funds to facilitate funding of collaborative management (e.g. contracts for livelihood development facilitators) in protected areas in Bangladesh, as implemented in Periyar Tiger Reserve, India.

\section{SUPPLEMENTARY ONLINE MATERIAL}

Appendix 1: Key institutional bodies in the Collaborative management system of Bangladesh, in 2016.

Appendix 2: Field projects promoting the collaborative management system in Bangladesh between 2003 and 2017

\section{ABOUT THE AUTHORS}

Md. Shams Uddin is a Forest Governance Consultant of UNDP for the UN-REDD+ Bangladesh National Programme. Before, he worked with Winrock International, Bangladesh Water Development Board, Intercooperation, TMSS and Proshika MUK. He has 20 years' experience in natural resources and protected areas management, climate change and environment management in government and NGO sectors. Mr. Uddin is experienced and highly competent in conducting research and presenting program achievements at national and international fora. $\mathrm{He}$ holds a M.Sc. in Environmental Science from the UNESCO-IHE Institute for Water Education, Netherlands.

J ohn W.K. Parr has worked primarily in South-east Asia for over 30 years. He specializes in analysing natural resource legislation to identify key institutional management bodies. In relation to government managed protected areas, he conducts institutional mapping of all involved stakeholder bodies and assesses their working inter-relationships within a multi-level collaborative management system. He promoted an interagency wildlife trade committee (Thai-WEN) in Thailand in 2003-2004, including law enforcement agencies, based upon the concept of the National Parks and Reserves Authority prescribed in the National Parks Act of New Zealand (1980). He founded the Bang Pu Nature Education Centre in Thailand.

\section{REFERENCES}

Abbasi, F. and Khan, A. (2009). Potential of community-based natural resource management to alleviate interlinked problems of poverty and conservation. ICFAI Journal of Environmental Economics, 7(2): 49-61.

Allendorf, T.D., Aung, M. and Songer, M. (2012). Using residents' perceptions to improve park-people relationships in Chattin Wildlife Sanctuary, Myanmar. Journal of Environmental Management, 99: 36-43. https://doi.org/10.1016/ j.jenvman.2012.01.004

Appleton, M.R., Texon, G.I. and Uriarte, M.T. (2003). Competence Standards for Protected Area Jobs in South East Asia. Los Baños, Philippines: ASEAN Regional Centre for Biodiversity Conservation. $104 \mathrm{pp}$.

Arnold, J.S. and Gimenez, F.M. (2007). Building special capital through participatory research: An analysis of collaboration on Tohono O'odham tribal rangelands in Arizona. Society and Natural Resources, 20: 481-495. https:// doi.org/10.1080/08941920701337887

Baldus, R.D. (2008). Wildlife: Can it pay its way or must it be subsidized? In: R.D. Baldus, G.R. Damn and K. Wollscheid (Eds.), Best practices in sustainable hunting: $A$ guide to best practices from around the world, pp.12-16. Budakeszi, Hungary: International Council for Game and Wildlife Conservation.

Berkes, F., George, P. and Preston, R. (1991). Co-management: The evolution of the theory and practice of joint administration of living resources. Alternatives, 18 (2): 12-18.

Borrini-Feyerabend, F.G., Michel, P., Farvar, M.T., Kothari, A. and Renard, Y. (2004). Sharing Power. Learning by doing in comanagement of natural resources throughout the world. IIED and IUCN/CEESP/CMWG, Cenesta, Tehran.

Cardinale, B.J., Duffy, J.E., Gonzalez, A., Hooper, D.U., Perrings, C. Venail, P., Narwani, A., Mace, G.M., Tilman, D. and Wardle, D.A. (2012). Biodiversity loss and its impact on humanity. Nature, 486: 59-67. https://doi.org/10.1038/nature11148

Carlsson, L. and Berkes, F. (2005). Co-management: Concepts and methodological implications. Journal of Environmental Management, 75: 65-76. http://dx.doi.org/10.1016/ j.jenvman.2004.11.008

Chowdhury, M.S.H. and Koike, M. (2010). An overview on the protected area system for forest conservation in Bangladesh. Journal of Forestry Research, 21(1): 111-118. http:// dx.doi.org/10.1007/s11676-010-0019-x

Chowdhury, M.S.H., Koike, M. and Muhammed, N. (2009). Embracing collaborative protected area management for conservation: An analysis of the development of the forest 
policy of Bangladesh. International Forestry Review 11: 359374. http://dx.doi.org/10.1505/ifor.11.3.359

Chowdhury, M.S.H., Nazia, N., Izumiyama, S., Muhammed, N. and Koike, M. (2014). Pattern and Extent of threats to the protected areas of Bangladesh: The need for a relook at conservation strategies. PARKS, 20 (1): 91-104. http:// dx.doi.org/10.2305/IUCN.CH.2014.PARKS-20-1.MSHC.en

De Koning, M., Parr, J.W.K., Sengchanthavong, S. and Phommasane, S. (2016). Collaborative governance improves management effectiveness of Hin Nam No National Protected Area in Central Lao PDR. PARKS 22 (2): 27-40. http://dx.doi.org/10.2305/ IUCN.CH.2016.PARKS-22-2MdK.en

Dhakal, B. and Thapa, B. (2015). Buffer Zone Management Issues in Chitwan National Park, Nepal: A Case Study of Kolhuwa Village Development Committee. PARKS, 21 (2): 63-72. http:// dx.doi.org/10.2305/IUCN.CH.2014.PARKS-21-2BD.en

Ferdous, F. (2015). Co-management approach and its impacts on social, economic and ecological developments: Lessons from Lawachara National Park, Bangladesh. International Journal of Research on Land-use Sustainability, 2: 91-98.

Fox, J., Bushley, B.R., Dutt, D. and Quazi, S.A. (2007). Making conservation work: Linking rural livelihoods and protected area management in Bangladesh. Honolulu and Dhaka: East-West Center and Nishorgo Program of the Bangladesh Forest Department.

Government of Bangladesh. (2009). Government of Bangladesh Gazette Notification No. pabama/parisha-4/nishorgo/105/ sting/2006/398 dt.23/11/2009. Dhaka: Ministry of Environment and Forests, Government of Bangladesh.

Haider, F. and Kabir, M.H. (2014). Preliminary impacts of a comanagement program at Lawachara National Park, Bangladesh. Journal of Biodiversity Management \& Forestry, 3: 1-6.

Huda, K.S. (2006). Co-management of protected areas in Bangladesh: A strategy for establishing an institutional framework. Dhaka: Nishorgo Support Project, Bangladesh Forest Department. Retrieved from http://www.nishorgo.org/ tbltd/upload/pdf/0.51609100\%201357822362_22_Co

Management\%20of\%20PAs\%20in\%20Bangladesha\% 20Strategy\%20for\%20Establishing\%20an\%20Institutional\% 20framework.pdf.

Jashimuddin, M. and Inoue, M. (2012). Community forestry for sustainable forest management: experiences from Bangladesh and policy recommendations. FORMATH, 11: 133-166. http:// dx.doi.org/10.15684/formath.11.133

Kolahi, M., Sakai, T., Moriya, K., Makhdoum, M.F. and Koyama, L. (2013). Assessment of the effectiveness of protected areas management in Iran: Case study in Khojir National Park. Environmental Management 52: 514-530. http:// dx.doi.org/10.1007/s00267-013-0061-5
Kopylova, S.L. and Danilina, N.R. (Eds.) (2011). Protected Area Staff Training: Guidelines for Planning and Management. Gland, Switzerland: IUCN. xiv + 102 pp.

Lynam, T., de Jong, W., Sheil, D., Kusumanto, T. and Evans, K. (2007). A review of tools for incorporating community knowledge, preferences, and values into decision making in natural resources management. Ecology and Society, (1): 5. http:// dx.doi.org/10.5751/ES-01987-120105

Mehta, J.N., and Heinen, J.T., (2001). Does community-based conservation shape favourable attitudes among locals? An empirical study from Nepal. Environmental Management 28, 2, 165-177. http://dx.doi.org: 10.1007/s002670010215

Mian, M.Z.R. (2011). Livelihoods of forest-dependent people in Kaptai National Park. In: J. Fox, M.G. Mustafa, S.A. Quazi, W.B. Miles, E.J. Cunningham and M. Chassels. (Eds). Rural livelihoods and protected landscapes: Co-management in the wetlands and forests of Bangladesh, pp. 138-155. East West Center, USAID, Integrated Protected Area Co-Management Project of the Forest Department.

Mian, M., Khan, M. and Baten, M. (2013). Impacts of Madhupur National Park on local peoples' livelihood. Journal of Environmental Science and Natural Resources, 5(2): 63-66. http://dx.doi.org/10.3329/jesnr.v5i2.14603

Muhammed, N., Koike, M. and Haque, F. (2008). Forest policy and sustainable forest management in Bangladesh: An analysis from national and international perspectives. New Forests, 36: 201216. http://dx.doi.org/10.1007/s11056-008-9093-8

Mukul, S.A., Rashid, M.A.Z.M., Shimona, A., Uddin, Q.M.B. and Fox, J. (2012). Local people's responses to co-management regime in protected areas: A case study from Satchari National Park, Bangladesh. Forest, Trees and Livelihoods, 21(1): 16-29. http:// dx.doi.org/10.1080/14728028.2012.669132

Mukul, S.A., Rashid, A.Z.M.M., Uddin, M.B. and Khan, N.A. (2016). Role of non-timber forest products in sustaining forest-based livelihoods and rural households' resilience capacity in and around protected area: A Bangladesh study. Journal of Environmental Planning and Management, 59 (4): 628-642. http://dx.doi/10.1080/09640568.2015.1035774

Mukul, S.A., Uddin, M.B., Manzoor Rashid, A.Z.M. and Fox, J. (2010). Integrating livelihoods and conservation in protected areas: Understanding the role and stakeholder views on prospects for non-timber forest products, a Bangladesh case study. International Journal of Sustainable Development \& World Ecology, $\quad 17(2)$ : 180-188. http:// dx.doi.org/10.1080/13504500903549676

Mulongoy, K.J., Gidda, S.B., Janishevski, L. and Cung, A. (2008). Current funding shortfalls and innovative funding mechanisms to implement the PoWPA. PARKS, 17: 31-36.

Nagothu, U.S. (2001). Fuelwood and fodder extraction and deforestation: Mainstream views in India discussed on the basis 
of data from the semi-arid region of Rajasthan. Geoforum, 32: 319-332. http://dx.doi.org/10.1016/S0016-7185(00)00034-8

Palomo, I., Montes, C., Martin-Lopez, B., Gonzalez, J.A., GarciaLlorente, M., Alcorlo, P. and Mora, M.R.G. (2014). Incorporating the Social-Ecological Approach in Protected Areas in the Anthropocene. BioScience, 33: 1-11. https:// doi.org/10.1093/biosci/bit033

Parr, J.W.K. (2015). Institutional analysis of multi-level collaborative management in Periyar Tiger Reserve, Southern India. PARKS: 21 (2): 37-50. http://dx.doi.org/10.2305/IUCN.CH.2014.PARKS21-2JWKP.en

Parr, J.W.K. (2017). Analysis of the multi-level collaborative management system in Mount Kitanglad Range Natural Park, Mindanao, Philippines. Ecosystems \& Development Journal 7 (1): 33-44.

Parr, J.W.K., Insua-Cao, P., Lam, H.V., Tue H.V., Ha, N.B., Lam, N.V., Quang N.N., The Cuong, N. and Crudge, B. (2013). Multi-level co-management in government-designate areas. Opportunities to learn from models in Southeast Asia. PARKS,19 (2): 59-64.

https://doi.org/10.2305/iucn.ch.2013.parks-19-2.en

Parry, D. and Campbell, B. (1992). Attitudes of rural communities to animal wildlife and its utilisation in the Chobe Enclave and the Mababe depression, Botswana. Environmental Conservation, 19: 245-252.

Pender, J.S. (2008). What Is Climate Change? And How It Will Effect Bangladesh. Briefing Paper. (Final Draft). Dhaka, Bangladesh: Church of Bangladesh Social Development Programme. Retrieved from: https://www.kirkensnodhjelp.no/ contentassets/c1403acd5da84d39a120090004899173/2008/ final-draft-what-is-climate-change-and-how-it-may-affectbangladesh.pdf. Accessed on 28 June 2016.

Quazi. S.A., Bushley, B.R. and Miles, W.B. (2008). Introduction: Participation and the Collaborative Management of Protected Areas in Bangladesh In: Fox. J., Bushley, B.R., Dutt. S., and Quazi, S.A.

. (eds). Connecting Communities and Conservation: Collaborative Management of Protected Areas in Bangladesh East West Center, USAID.

Rahman, S.S. and Vacik, H. (2015). Identify appropriate conservation strategies for rural people in Bangladesh. Journal of Biodiversity Management \& Forestry, 4(1), 1-12. https:// doi.org/10.4172/2327-4417.1000137

Rashid, M.A.Z.M., Craig, D. and Mukul, S.A. (2013). A journey towards shared governance: Status and prospects for collaborative management in the protected areas of Bangladesh. Journal of Forestry Research, 24 (3): 599-605. https://doi.org/10.1007/s11676-013-0391-4
Rashid, M.A.Z.M., Craig, D. and Khan, N.A. (2015). Selected dynamics of collaborative protected area management in the Global North and South: Experiences from Australia and Nepal. International Journal of Research on Land-use Sustainability, 2: 113-124. https://doi.org/10.13140/RG.2.1.1297.2402

Rashid, M. A.Z.M., Craig, D. and Mukul, S.A. (2017). Shifting paradigm of governance in the natural resource management of Bangladesh: A centralist to pluralistic approach in the forest protected areas management. In: S.A. Mukul and A.Z.M.M. Rashid, Protected Areas: Policies, Management \& Future Directions, Chapter 3. Nova Science Publishers.

Sharma, R., DeCosse, P. and Khan, M. (2008). Co-Management of Protected Areas in South Asia with Special Reference to Bangladesh. Dhaka: Nishorgo Support Project, Bangladesh Forest Department.

Sohel, M.S.I., S.A. Mukul, and B. Burkhard. 2014. "Landscapes capacities to supply ecosystem services in Bangladesh; a mapping assessment for Lawachara National Park." Ecosystem services 12: 1-8. http://doi.org:10.1016/j.ecoser.2014.11.01.

Steinmetz, R., Srirattanaporn, S., Mor-Tip, J. and Seuaturien, N. (2014). Can community outreach alleviate poaching pressure and recover wildlife in South-East Asian protected areas? Journal of Applied Ecology, 51 (6): 1469-1478. http:// dx.doi.org/10.1111/1365-2664.12239

Uddin M.A. and Foisal, A.S.A. (2007). Local perceptions of natural resource conservation in Chunati Wildlife Sanctuary. In: J. Fox, B.R. Bushley, S. Dutt and S.A. Quazi (Eds.), Making conservation work: Linking rural livelihoods and protected area management in Bangladesh, pp. 84-109. Honolulu, Hawaii: East West Centre.

Uddin, M.B. and Mukul, S.A. (2007). Improving forest dependent livelihood through NTFPs and home gardens. A case study from Satchari National Park. In: J. Fox, B.R. Bushley, S. Dutt and S.A. Quazi (Eds.), Making conservation work: Linking rural livelihoods and protected area management in Bangladesh, pp. 13-35. Honolulu, Hawaii: East West Centre.

Weladji, R.B., Moe, R.S. and Vedeld, P. (2003). Stakeholder attitudes towards wildlife policy and the Bénoué Wildlife Conservation Area, North Cameroon. Environmental Conservation, 30 (4): 334-343. http://dx.doi.org/10.1017/\$0376892903000353.

World Bank. (1999). Report from the International Workshop on Community-Based Natural Resource Management (CBNRM). Washington, DC, 10-14 May 1998. 


\section{RESUMEN}

El sistema de áreas protegidas de Bangladesh comprende 17 parques nacionales que abarcan 45.740 hectáreas y 21 santuarios de vida silvestre que cubren 394.053 hectáreas (a marzo de 2017). El Gobierno de Bangladesh introdujo la gestión participativa en estas reservas en tres etapas sucesivas y en expansión, emprendidas entre 2003 y hasta hoy día. Durante este período, los programas sucesivos introdujeron un elaborado sistema de gestión participativa. El presente artículo evalúa tanto el sistema de gestión participativa como los acuerdos de gestión de áreas protegidas que se promueven, los cuales incluyen: (i) el Consejo de cogestión, (ii) el Comité de cogestión, (iii) los Foros del pueblo y (iv) los órganos institucionales de subaldeas, incluidos los Comités de vigilancia participativa y los Grupos de usuarios de los bosques (o los Foros de conservación de las aldeas). Evalúa las intervenciones de gestión y la eficacia del sistema de gestión participativa para implementar un programa eficaz para la gestión de áreas protegidas. El examen indica que la organización y el mandato actual de las autoridades de áreas protegidas les impide ser socios eficaces en la gestión participativa, careciendo de personal dedicado tanto en términos de los programas de proyección como de medios de subsistencia, lo cual socava su participación en la gestión colaborativa. Este artículo recomienda el fortalecimiento y reorganización de las autoridades responsables de las áreas protegidas, para que desempeñen un papel preponderante en la participación a nivel de aldeas y que puedan actuar como organismo coordinador clave en los órganos de gestión participativa de más alto nivel.

\section{RÉSUMÉ}

Le système d'aires protégées du Bangladesh comprend 17 parcs nationaux qui s'étendent sur 45740 hectares, et 21 réserves fauniques englobant un total de 394053 hectares (en mars 2017). Le gouvernement du Bangladesh a mis en place la gestion collaborative dans ces réserves en trois phases successives et progressives, entreprises entre 2003 et aujourd'hui. Au cours de cette période, les programmes successifs ont mis en oeuvre un système de gestion collaboratif élaboré. Cet article évalue ce système de gestion collaboratif ainsi que les dispositions de gestion en cours d'implémentation dans les aires protégées, comprenant (i) le Conseil de Cogestion, (ii) le Comité de Cogestion, (iii) le Forum Populaire, et (iv) les organismes institutionnels des villages, y compris les groupes de patrouilles communautaires et les groupes d'usagers forestiers (ou les forums de conservation des villages). Il évalue le rôle des interventions administratives et de la gestion collaborative dans la mise en ouvre d'un programme efficace dans les aires protégées. Cet étude indique que l'organisation et le mandat actuel des autorités des aires protégées ne permet pas leur implication efficace dans la gestion collaborative, car ils manquent de personnel dédié aux programmes de sensibilisation et de subsistance, ce qui entrave sérieusement leur participation à la gestion collaborative. Ce document recommande que l'autorité des aires protégées soit renforcée et réorganisée, afin de leur permettre de jouer un rôle de premier plan dans l'engagement des villages - et d'occuper une position clé au sein des organes de gestion collaborative au plus haut niveau. 